\title{
Fuzzy logic algorithm and analytic network process (ANP) for boarding houses searching recommendations
}

\author{
Wawan Gunawan \\ Universitas Mercu Buana, Jl. Meruya Selatan No. 1, Kembangan, Jakarta Barat 11650, Indonesia \\ wawan.gunawan@mercubuana.ac.id
}

Article history: Received February 2, 2021; Revised April 26, 2021; Accepted April 28, 2021; Available online April 30, 2021

\begin{abstract}
Finding a boarding house is usually done manually or by visiting the boarding house in person. Several choices of boarding houses make boarding house seekers have to make choices according to the desired criteria, so it takes quite a long time. A decision support system is a system that can be used to help make decisions based on existing criteria for determining several alternatives to be selected. The methods used in this research are the Analytic Network Process (ANP) and the Fuzzy Logic method. This study employed several criteria in providing recommendations, including distance, price, facilities, security, number of spaces, parking space and convenience. The weighting of these criteria used the fuzzy logic method based on the priority scale determined by the boarding house seekers. This system has provided a recommendation for boarding houses based on the results of the calculation process using the ANP method and weighting using fuzzy logic. The result of calculations shows that the highest value was obtained by Munawar kos (boarding house) with a value of $6.55 \%$ and followed by Diding kos with a value of $6.52 \%$.
\end{abstract}

Keywords: Analytic Network Process; Fuzzy Logic; DSS; Boarding house; Recommendation

\section{Introduction}

Currently, many employees and students from outside the city live in boarding houses because it can save time and transportation costs. It will be exhausting for them to go back and forth from their hometown to their workplaces and schools. The problem occurs when they want to find a boarding house that fits the criteria, as they have to search from one boarding house to another [1]. There are certain criteria for boarding house seekers to get the right and appropriate boarding house [2] [3]. However, limited information regarding the location, price, facilities and contact of the boarding house owner is the common problem often faced by them.

A study used the SAW (Simple Additive Weighting) method using 3 criteria, namely a) price; b) location; c) facilities and using 3 alternatives, obtained the best alternative output value of 3.99 [4]. Another study used the Analytic Network Process (ANP) method for the selection of boarding houses using 3 criteria, namely a) distance; b) price; c) facilities and using 30 alternative boarding houses obtained the result of 3,714 for Kos Putri (female boarding house) and then 3,702 for Asenkar boarding house [5].

In addition, a study using Fuzzy Sugeno employed 6 criteria, namely price, rooms, location of the market, nearby dining places, places of worship, and parking lots [6]. To obtain the result in this study, four stages of data collection were conducted; they included the formation of fuzzy sets, the formation of rules, application of implication functions and rule inference as well as defuzzification. Some of the main components in choosing the ideal house are accessibility and flooding avoidance [7], safety and convenience standards, i.e., parking availability, safe neighbourhood (from thefts and sexually immoral acts), adequate lighting, good air circulation, provision of clean water and windows [8] [9].

In addition, there are several health requirements for housing needed by humans such as oxygen, availability of clean water, air circulation, density of occupancy, disposal of waste, environmental facilities, and infrastructure as well as reforestation [10]. Referring to previous research in finding boarding houses that used 3 criteria, namely distance, price, and bathroom facilities, this study adds several criteria such as price, facilities, security [11], distance, convenience, parking space, and the number of spaces. 12]. It is hoped that the addition of the criteria can produce a system that is able to overcome the problems mentioned above. 


\section{Method}

\section{A. Fuzzy Logic}

The weighting of the criteria to be used is based on the priority determined by the boarding house seekers so that the weight can be determined using fuzzy logic. In this study, 7 criteria were proposed, and the boarding house seekers could choose all of these criteria, or it could be less than 7 criteria, depending on their needs.

In this study, the criteria used include rental prices, available facilities, security, distance, convenience, parking space and the number of spaces. These criteria can be selected by the seekers based on the order of priority, whether the main priority is based on distance, or based on price, and so on. The priority can be described as in Figure 1.

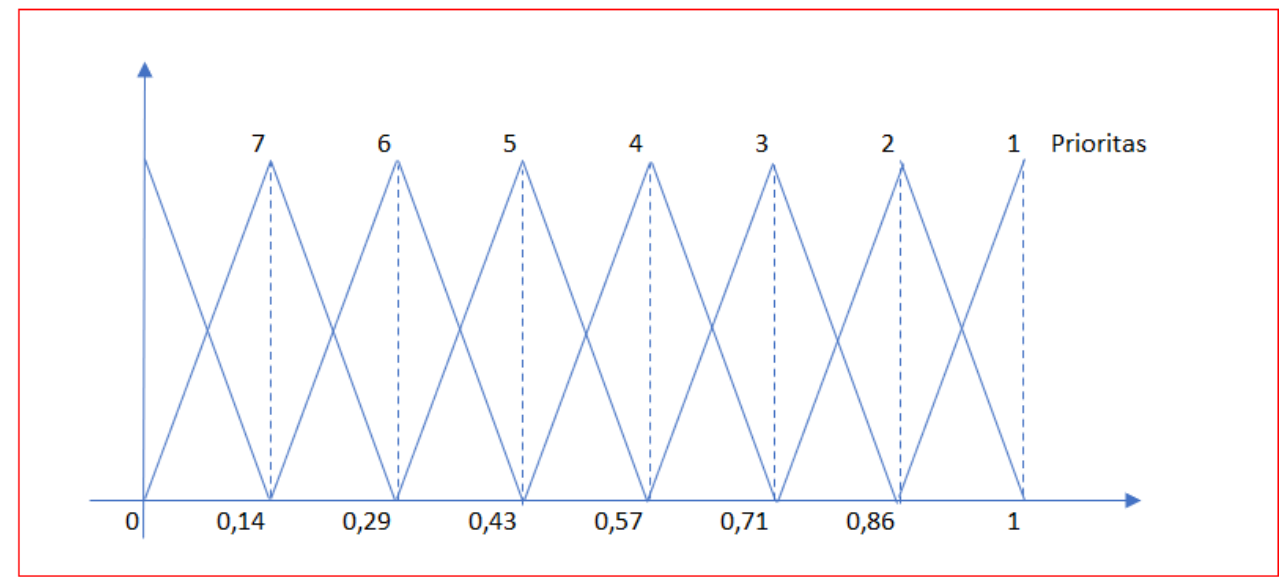

Figure 1. Fuzzy logic weighting

The equation (1) is:

Weighting $=(($ count $-n)+1) x(1 /$ count $) \times 100$

Count $=$ number of priority

$\mathrm{N}=$ priority order

\section{B. Analytic Network Process (ANP)}

The Analytic Network Process (ANP) method is a qualitative approach developed to improve the weaknesses of the Analytical Hierarchy Process (AHP) method in the form of the ability to recommend linkages to the ANP method [13]. The Analytical Network Process (ANP) method is a mathematical theory that is able to analyze an effect by using an assumption approach to solve problems. This method is used with consideration of adjusting the complexity of the problem by means of a synthesis decomposition accompanied by a priority scale that produces the greatest priority effect. In the AHP network there are levels of objectives, criteria, sub-criteria, and alternatives, each of which has elements. Whereas in the ANP network, the level in AHP is called a cluster which can have criteria and alternatives in it [14]

The advantage of the ANP method when compared to AHP is in solving more complex problems [15]. Research using the Analytic Network Process (ANP) method is the right solution in determining priority road handling based on the level of road service. The study shows a correlation value between -1 to 1 with a value of 0.867 which has been validated using the Spearman Rank for 10 roads in the city of Cirebon [16]. The steps used to solve this problem are:

1. Identify problems and determine solution criteria.

2. Determine the weighting of the criteria by the user

3. Create a Comparison Matrix

Comparison matrix is done by making comparisons in pairs for each hierarchical sub-system, then transforming it in the form of a matrix for a numerical analysis process ( $\mathrm{n} \times \mathrm{n}$ matrix). Comparison matrixe is shown in Table $\mathbf{1}$.

Table 1. Comparison matrix

\begin{tabular}{|c|c|c|c|c|c|}
\hline $\boldsymbol{A}$ & B1 & $B 2$ & B3 & $\ldots$ & $B n$ \\
\hline B1 & B11 & B12 & B13 & $\ldots$ & B1n \\
\hline B2 & B21 & B22 & B23 & $\ldots$ & B2n \\
\hline B3 & B31 & B32 & B33 & . & B3n \\
\hline$\ldots$ & $\ldots$ & $\ldots$ & $\ldots$ & $\ldots$ & $\ldots$ \\
\hline$\ldots \ldots$ & $\ldots \ldots$ & $\ldots$ & $\ldots$ & $\ldots$ & . \\
\hline $\mathrm{Bn}$ & Bn1 & $\mathrm{Bn} 2$ & $\mathrm{Bn} 3$ & & $\mathrm{Bnn}$ \\
\hline
\end{tabular}

4. Calculating the Eigenvector Value 
To calculate the eigenvector value, we added up the values in each column of the matrix then divided each value in the column cell by the total column, then added up the values for each row and divide by the value of $\mathrm{n}$. The calculation of the eigenvector value can be seen in equation (2).

$$
X=\sum\left(\frac{W_{i}}{\sum W_{i}}\right)
$$

$\mathrm{X}=$ eigenvector

$\mathrm{Wi}=$ single row column cell value $(\mathrm{i}=1 \ldots \mathrm{n})$

$\sum \mathrm{W} \_\mathrm{i}=$ total number of columns

5. Checking Consistency Ratio

a. Looking for the value of $\lambda$ maks shown in equation (3)

$\lambda$ maks $=($ eigenvector value $1 \times$ number of columns 1$)+$

(eigenvector value $2 \times$ number of columns 2 ) ... n

b. Calculating the Consistency Index (CI), with equation (4).

$\mathrm{CI}=((\lambda$ maks-n) $) /((\mathrm{n}-1))$

Where:

$\mathrm{CI}=$ Consistency Index

$\lambda$ maks $=$ the largest eigenvector value

$\mathrm{n}=$ number of comparison matrices

c. Determining Consistency Ratio (CR)

$C R=C I / R I$

Table 2. Random Index Value

\begin{tabular}{|l|l|l|l|l|l|l|l|l|l|}
\hline Orde Matrix & $\mathbf{1}$ & $\mathbf{2}$ & $\mathbf{3}$ & $\mathbf{4}$ & $\mathbf{5}$ & $\mathbf{6}$ & $\mathbf{7}$ & & $\mathbf{9}$ \\
\hline $\mathrm{RI}$ & 0 & 0 & 0.58 & 0.9 & 1.12 & 1.24 & 1.32 & 1.41 & 1.45 \\
\hline
\end{tabular}

CR will have a better value and can show its consistency if it is close to zero in the comparison matrix. Random Index Value is shown in Table 2.

6. Making Supermatrix

There are 3 types of supermatrix in ANP.

a. Unweight supermatrix, the eigenvector generated from the whole pairwise comparison matrix in the network.

b. Weighted supermatrix, multiplying the contents of the unweighted supermatrix with the cluster weight.

c. Limit supermatrix, performing the weighted supermatrix continuously until the number in each column in one row is the same then normalize.

7. Ranking

It is the final value in the ANP method that has been carried out by the normalization process to find out the final value of the calculation. The best alternative is generated from the highest alternative score [16].

\section{Methodology}

In this study, our methodology is as shown in Figure 2. 


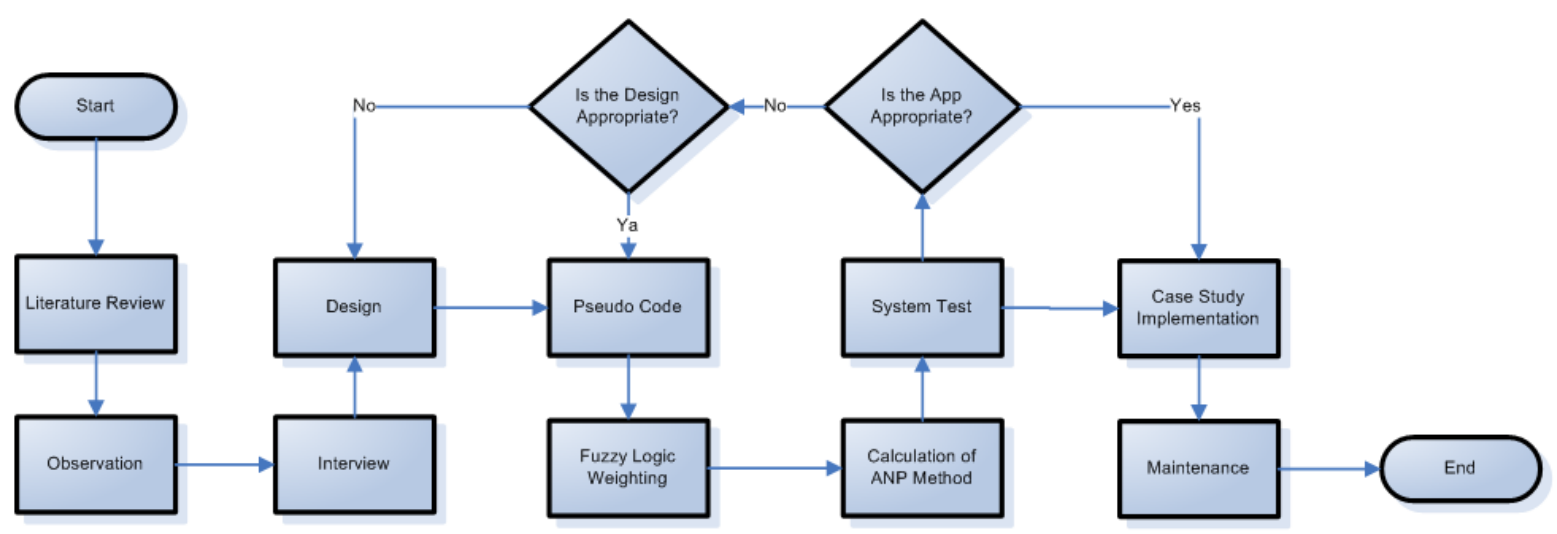

Figure 2. Methodology

This research was conducted with the following stages:

1. Interview

The interview was conducted to know the business process in searching for boarding houses manually by conducting questions and answers to employees and students in order to get precise and accurate results.

2. Observation

The researcher collected data based on predetermined criteria for several boarding houses in Tangerang area.

3. Literature/Library Studies

The data was further analyzed by studying several journals related to the search for boarding houses including the criteria used [17].

\section{Results and Discussion}

\section{A. Design}

In this study, the boarding house seekers used 7 selected criteria with top priority starting from the price offered, the facilities provided, the security of the boarding house whether security was available or not, the distance from the boarding house to the place of activity, the convenience of the boarding house, the availability of parking lot both car parking and motorbike parking, and the last priority is the number of rooms in the boarding house. Based on equation 1, the weights for each criterion were obtained as shown in Table 3.

Table 3. Weighting criteria

\begin{tabular}{|l|l|l|l|}
\hline Priority & Code & Criteria & Weight \\
\hline 1 & H & Price & 100 \\
\hline 2 & F & Facility & 86 \\
\hline 3 & KA & Security & 71 \\
\hline 4 & J & Distance & 57 \\
\hline 5 & KN & Convenience & 43 \\
\hline 6 & P & Parking lot & 29 \\
\hline 7 & R & Number of rooms & 14 \\
\hline
\end{tabular}

After the weight value was determined by the user, then the researcher made a pairwise comparison matrix as shown in Table 4.

Table 4. Comparison matrix

\begin{tabular}{|l|l|l|l|l|l|l|l|}
\hline Criteria & H & F & KA & J & KN & P & R \\
\hline H & 1.00 & 1.16 & 1.41 & 1.75 & 2.33 & 3.45 & 7.14 \\
\hline F & 0.86 & 1.00 & 1.21 & 1.51 & 2.00 & 2.97 & 6.14 \\
\hline
\end{tabular}




\begin{tabular}{|l|l|l|l|l|l|l|l|}
\hline Criteria & H & F & KA & J & KN & P & R \\
\hline KA & 0.71 & 0.83 & 1.00 & 1.25 & 1.65 & 2.45 & 5.07 \\
\hline J & 0.57 & 0.66 & 0.80 & 1.00 & 1.33 & 1.97 & 4.07 \\
\hline KN & 0.43 & 0.50 & 0.61 & 0.75 & 1.00 & 1.48 & 3.07 \\
\hline $\mathrm{P}$ & 0.29 & 0.34 & 0.41 & 0.51 & 0.67 & 1.00 & 2.07 \\
\hline $\mathrm{R}$ & 0.14 & 0.16 & 0.20 & 0.25 & 0.33 & 0.48 & 1.00 \\
\hline$\Sigma$ & 4.00 & 4.65 & 5.63 & 7.02 & 9.30 & 13.79 & 28.57 \\
\hline
\end{tabular}

The next step was to determine the eigenvector value using the equation (2) by adding up the value of each row from the matrix and then dividing each value of the number of row cells by the total column. The eigenvector value is shown in Table 5.

Table 5. Eigen value

\begin{tabular}{|l|l|l|}
\hline Criteria code & Total & Eigen \\
\hline $\mathrm{H}$ & 18.24 & 0.25 \\
\hline $\mathrm{F}$ & 15.69 & 0.22 \\
\hline $\mathrm{KA}$ & 12.95 & 0.18 \\
\hline $\mathrm{J}$ & 10.40 & 0.14 \\
\hline $\mathrm{KN}$ & 7.84 & 0.11 \\
\hline $\mathrm{P}$ & 5.29 & 0.07 \\
\hline $\mathrm{R}$ & 2.55 & 0.04 \\
\hline $\mathrm{E}$ & 72.97 & 100 \\
\hline
\end{tabular}

Furthermore, after the eigenvector value is obtained, the next step was to check the consistency ratio using the formula in equation 3 , if the value is $<0.1$ then results are consistent.

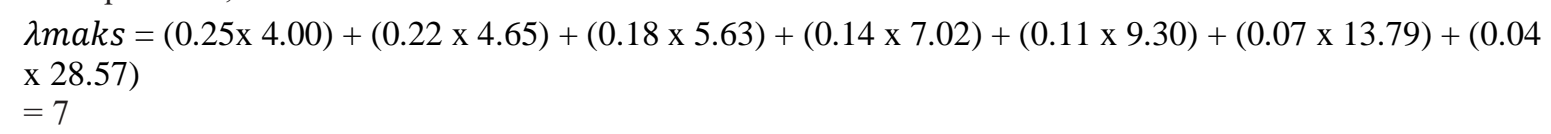

Next was calculating CI with the number of orders using 7 criteria. To calculate CI the equation (4) was used.

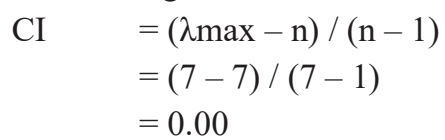

The Random Index (RI) used is 1.32 based on the value specified in table 2 . The calculation of the CR value can use equation (5).

$$
\begin{aligned}
\mathrm{CR} & =\mathrm{CI} / \mathrm{RI} \\
& =0.00 / 1.32 \\
& =0.00
\end{aligned}
$$

Because the $\mathrm{CR}$ result is 0.00 less than $0.10(\mathrm{CR}<0.1)$, the eigenvector value is considered consistent.

The next step was to calculate the eigenvector price using the equation (2). The first step was to calculate the reverse value. The reverse price value is to reverse the value by subtracting the total price value by the price value of each Kos (boarding house). After that, the eigenvector value was obtained by dividing each reserve value of Kos by the total reverse price. Table 6 is the result of the eigenvector price calculation.

Table 6. Eigenvector Price

\begin{tabular}{|l|l|l|l|l|}
\hline No & Alternative & Price Value & Reverse Price & Eigen vector \\
\hline 1 & Mariyam Kos & 850,000 & $13,455,000$ & 0.0495 \\
\hline 2 & Hariyono Kos & 800,000 & $13,505,000$ & 0.0497 \\
\hline 3 & Deni Kos & 750,000 & $13,555,000$ & 0.0499 \\
\hline
\end{tabular}




\begin{tabular}{|l|l|l|l|l|}
\hline No & Alternative & Price Value & Reverse Price & Eigen vector \\
\hline 4 & Budi Kos & 650,000 & $13,655,000$ & 0.0502 \\
\hline 5 & Sinta Kos & 700,000 & $13,605,000$ & 0.0501 \\
\hline 6 & Aldian Kos & 615,000 & $13,690,000$ & 0.0504 \\
\hline 7 & Doni Kos & 800,000 & $13,505,000$ & 0.0497 \\
\hline 8 & Munawar Kos & 800,000 & $13,505,000$ & 0.0497 \\
\hline 9 & Andreas Kos & 580,000 & $13,725,000$ & 0.0505 \\
\hline 10 & Harry Kos & 850,000 & $13,455,000$ & 0.0495 \\
\hline 11 & Rika Kos & 550,000 & $13,755,000$ & 0.0506 \\
\hline 12 & Riski Kos & 700,000 & $13,605,000$ & 0.0501 \\
\hline 13 & Dedi Kos & 560,000 & $13,745,000$ & 0.0506 \\
\hline 14 & Dede Kos & 600,000 & $13,705,000$ & 0.0504 \\
\hline 15 & Anang Kos & 570,000 & $13,735,000$ & 0.0505 \\
\hline 16 & Mariya Kos & 750,000 & $13,555,000$ & 0.0499 \\
\hline 17 & Slamet Kos & 900,000 & $13,505,000$ & 0.0493 \\
\hline 18 & Diding Kos & 850,000 & $13,405,000$ & 0.0495 \\
\hline 19 & Yanto Kos & 880,000 & $13,455,000$ & 0.0494 \\
\hline 20 & Nurul Kos & 550,000 & $13,425,000$ & 0.0506 \\
\hline & $\sum$ & $14,305,000$ & $271,795,000$ & 1 \\
\hline & & & & \\
\hline
\end{tabular}

The second criterion is that the facility that used equation (2) without using the reverse process, because the higher the facility value, the better. The calculation process is the value of each facility divided by the total value of all Kos facilities. Table 7 is the result of the calculation of the eigenvector facility.

Table 7. Eigenvector Facility

\begin{tabular}{|c|c|c|c|}
\hline No & Alternative & Facility value & Eigen vector \\
\hline 1 & Mariyam Kos & 4 & 0.0727 \\
\hline 2 & Hariyono Kos & 4 & 0.0727 \\
\hline 3 & Deni Kos & 1 & 0.0182 \\
\hline 4 & Budi Kos & 1 & 0.0182 \\
\hline 5 & Sinta Kos & 1 & 0.0182 \\
\hline 6 & Aldian Kos & 1 & 0.0182 \\
\hline 7 & Doni Kos & 4 & 0.0727 \\
\hline 8 & Munawar Kos & 4 & 0.0727 \\
\hline 9 & Andreas Kos & 1 & 0.0182 \\
\hline 10 & Harry Kos & 4 & 0.0182 \\
\hline 11 & Rika Kos & 1 & 0.0182 \\
\hline 12 & Riski Kos & 4 & 0.0727 \\
\hline 13 & Dedi Kos & 1 & 0.0182 \\
\hline 14 & Dede Kos & 1 & 0.0182 \\
\hline 15 & Anang Kos & 1 & 0.0182 \\
\hline 16 & Mariya Kos & 4 & 0.0727 \\
\hline 17 & Slamet Kos & 4 & 0.0727 \\
\hline 18 & Diding Kos & 7 & 0.1273 \\
\hline 19 & Yanto Kos & 4 & 0.0727 \\
\hline 20 & Nurul Kos & 3 & 0.0545 \\
\hline
\end{tabular}




\begin{tabular}{|l|l|l|l|}
\hline No & Alternative & Facility value & Eigen vector \\
\hline & $\sum$ & 55 & 1 \\
\hline
\end{tabular}

The third criterion is security using equation (2). The calculation process is the same as finding the eigenvector facility where the higher the security value, the better, so the calculation process is the value of each security divided by the total security value of all Kos. Table 8 is the result of the calculation of the eigenvector security.

Table 8. Eigenvector Security

\begin{tabular}{|c|c|c|c|}
\hline No & Alternative & Security Value & Eigen vector \\
\hline 1 & Mariyam Kos & 1 & 0.0435 \\
\hline 2 & Hariyono Kos & 1 & 0.0435 \\
\hline 3 & Deni Kos & 1 & 0.0435 \\
\hline 4 & Budi Kos & 1 & 0.0435 \\
\hline 5 & Sinta Kos & 2 & 0.0870 \\
\hline 6 & Aldian Kos & 1 & 0.0435 \\
\hline 7 & Doni Kos & 1 & 0.0435 \\
\hline 8 & Munawar Kos & 2 & 0.0870 \\
\hline 9 & Andreas Kos & 1 & 0.0435 \\
\hline 10 & Harry Kos & 1 & 0.0435 \\
\hline 11 & Rika Kos & 1 & 0.0435 \\
\hline 12 & Riski Kos & 1 & 0.0435 \\
\hline 13 & Dedi Kos & 1 & 0.0435 \\
\hline 14 & Dede Kos & 1 & 0.0435 \\
\hline 15 & Anang Kos & 1 & 0.0435 \\
\hline 16 & Mariya Kos & 2 & 0.0870 \\
\hline 17 & Slamet Kos & 1 & 0.0435 \\
\hline 18 & Diding Kos & 1 & 0.0435 \\
\hline 19 & Yanto Kos & 1 & 0.0435 \\
\hline \multirow[t]{2}{*}{20} & Nurul Kos & 1 & 0.0435 \\
\hline & $\sum$ & 23 & 1 \\
\hline
\end{tabular}

The fourth criterion is the distance using the equation (2). The calculation process is the same as finding the eigenvector price by calculating the reverse value by subtracting the total value of the distance by the value of the distance of each Kos. After that, to find the eigenvector value, we divided the value of each reverse Kos distance by the total reverse distance. Table 9 is the result of calculating the eigenvector distance.

Table 9. Eigenvector Distance

\begin{tabular}{|l|l|l|l|l|}
\hline No & Alternative & Distance value & Reverse distance & Eigen vector \\
\hline 1 & Mariyam Kos & 10,000 & 253,700 & 0.05063569 \\
\hline 2 & Hariyono Kos & 8,800 & 254,900 & 0.050875197 \\
\hline 3 & Deni Kos & 10,000 & 253,700 & 0.05063569 \\
\hline 4 & Budi Kos & 9,900 & 253,800 & 0.050655649 \\
\hline 5 & Sinta Kos & 9,300 & 254,400 & 0.050775403 \\
\hline 6 & Aldian Kos & 79,000 & 184,700 & 0.03686406 \\
\hline 7 & Doni Kos & 9,500 & 254,200 & 0.050735485 \\
\hline 8 & Munawar Kos & 10,000 & 253,700 & 0.05063569 \\
\hline 9 & Andreas Kos & 10,000 & 253,700 & 0.05063569 \\
\hline 10 & Harry Kos & 10,000 & 253,700 & 0.05063569 \\
\hline 11 & Rika Kos & 10,000 & 253,700 & 0.05063569 \\
\hline
\end{tabular}




\begin{tabular}{|l|l|l|l|l|}
\hline No & Alternative & Distance value & Reverse distance & Eigen vector \\
\hline 12 & Riski Kos & 9,600 & 254,100 & 0.050715526 \\
\hline 13 & Dedi Kos & 11,000 & 252,700 & 0.050436102 \\
\hline 14 & Dede Kos & 10,000 & 253,700 & 0.05063569 \\
\hline 15 & Anang Kos & 10,000 & 253,700 & 0.05063569 \\
\hline 16 & Mariya Kos & 9,300 & 254,400 & 0.050775403 \\
\hline 17 & Slamet Kos & 9,300 & 254,400 & 0.050775403 \\
\hline 18 & Diding Kos & 8,000 & 255,700 & 0.051034868 \\
\hline 19 & Yanto Kos & 10,000 & 253,700 & 0.05063569 \\
\hline 20 & Nurul Kos & 10,000 & 253,700 & 0.05063569 \\
\hline & $\sum$ & 263,700 & $5,010,300$ & 1 \\
\hline
\end{tabular}

The fifth criterion is the convenience, using the equation (2), the calculation process is the same as finding the facility eigenvector. The result is in Table $\mathbf{1 0}$.

Table 10. Eigenvector convenience

\begin{tabular}{|c|c|c|c|}
\hline No & Alternative & Convenience Value & Eigen vector \\
\hline 1 & Mariyam Kos & 3 & 0.05 \\
\hline 2 & Hariyono Kos & 3 & 0.05 \\
\hline 3 & Deni Kos & 3 & 0.05 \\
\hline 4 & Budi Kos & 3 & 0.05 \\
\hline 5 & Sinta Kos & 3 & 0.05 \\
\hline 6 & Aldian Kos & 3 & 0.05 \\
\hline 7 & Doni Kos & 3 & 0.05 \\
\hline 8 & Munawar Kos & 3 & 0.05 \\
\hline 9 & Andreas Kos & 3 & 0.05 \\
\hline 10 & Harry Kos & 3 & 0.05 \\
\hline 11 & Rika Kos & 3 & 0.05 \\
\hline 12 & Riski Kos & 3 & 0.05 \\
\hline 13 & Dedi Kos & 3 & 0.05 \\
\hline 14 & Dede Kos & 3 & 0.05 \\
\hline 15 & Anang Kos & 3 & 0.05 \\
\hline 16 & Mariya Kos & 3 & 0.05 \\
\hline 17 & Slamet Kos & 3 & 0.05 \\
\hline 18 & Diding Kos & 3 & 0.05 \\
\hline 19 & Yanto Kos & 3 & 0.05 \\
\hline \multirow[t]{2}{*}{20} & Nurul Kos & 3 & 0.05 \\
\hline & $\Sigma$ & 60 & 1 \\
\hline
\end{tabular}

The sixth criterion is the parking lot using the equation (2). The calculation process is the same as finding the facility eigenvector. The result is in Table 11.

Table 11. Eigenvector Parking Lot

\begin{tabular}{|l|l|l|l|}
\hline No & Alternative & Parking lot Value & Eigen vector \\
\hline 1 & Mariyam Kos & 2 & 0.0909 \\
\hline 2 & Hariyono Kos & 1 & 0.0455 \\
\hline
\end{tabular}




\begin{tabular}{|l|l|l|l|}
\hline No & Alternative & Parking lot Value & Eigen vector \\
\hline 3 & Deni Kos & 1 & 0.0455 \\
\hline 4 & Budi Kos & 1 & 0.0455 \\
\hline 5 & Sinta Kos & 1 & 0.0455 \\
\hline 6 & Aldian Kos & 1 & 0.0455 \\
\hline 7 & Doni Kos & 1 & 0.0455 \\
\hline 8 & Munawar Kos & 2 & 0.0909 \\
\hline 9 & Andreas Kos & 1 & 0.0455 \\
\hline 10 & Harry Kos & 1 & 0.0455 \\
\hline 11 & Rika Kos & 1 & 0.0455 \\
\hline 12 & Riski Kos & 1 & 0.0455 \\
\hline 13 & Dedi Kos & 1 & 0.0455 \\
\hline 14 & Dede Kos & 1 & 0.0455 \\
\hline 15 & Anang Kos & 1 & 0.0455 \\
\hline 16 & Mariya Kos & 1 & 0.0455 \\
\hline 17 & Slamet Kos & 1 & 0.0455 \\
\hline 18 & Diding Kos & 1 & 0.0455 \\
\hline 19 & Yanto Kos & 1 & 0.0455 \\
\hline 20 & Nurul Kos & 1 & 0.0455 \\
\hline & $\sum$ & & 1 \\
\hline & & 22 & \\
\hline
\end{tabular}

The seventh criterion is the amount of space using the equation (2). The calculation process is the same as searching for the eigenvector of facilities where the higher the value of the number of spaces, the better, so the calculation process is the value of each number of rooms divided by the total value of the total number of rooms for all Kos. Table 12 is the result of the calculation of the eigenvector of the number of spaces.

Table 12. Eigenvector Number of Spaces

\begin{tabular}{|l|l|l|l|}
\hline No & Alternative & Number of Spaces Value & Eigen vector \\
\hline 1 & Mariyam Kos & 3 & 0.0811 \\
\hline 2 & Hariyono Kos & 3 & 0.0811 \\
\hline 3 & Deni Kos & 2 & 0.0541 \\
\hline 4 & Budi Kos & 1 & 0.0270 \\
\hline 5 & Sinta Kos & 1 & 0.0270 \\
\hline 6 & Aldian Kos & 1 & 0.0270 \\
\hline 7 & Doni Kos & 2 & 0.0541 \\
\hline 8 & Munawar Kos & 3 & 0.0811 \\
\hline 9 & Andreas Kos & 1 & 0.0270 \\
\hline 10 & Harry Kos & 3 & 0.0811 \\
\hline 11 & Rika Kos & 1 & 0.0270 \\
\hline 12 & Riski Kos & 2 & 0.0541 \\
\hline 13 & Dedi Kos & 1 & 0.0270 \\
\hline 14 & Dede Kos & 1 & 0.0270 \\
\hline 15 & Anang Kos & 1 & 0.0270 \\
\hline 16 & Mariya Kos & 2 & 0.0541 \\
\hline 17 & Slamet Kos & 3 & 0.0811 \\
\hline 18 & Diding Kos & 2 & 0.0541 \\
\hline
\end{tabular}




\begin{tabular}{|l|l|l|l|}
\hline No & Alternative & Number of Spaces Value & Eigen vector \\
\hline 19 & Yanto Kos & 3 & 0.0811 \\
\hline 20 & Nurul Kos & 1 & 0.0270 \\
\hline & $\sum$ & 37 & 1 \\
\hline
\end{tabular}

After obtaining each priority criterion, the eigenvector value of each cost was obtained, and the unweighted supermatrix was compiled from all the eigenvector values from the previous calculation. After that the value of the unweighted supermatrix was multiplied by the eigenvector from the results of the pairwise comparison matrix of criteria weights to produce the weighted supermatrix value. The final step was to iterate over the weighted supermatrix with itself so that the same value was obtained in each row for the limiting supermatrix process. To generate a global priority value, we calculated the alternative data of the Kos multiplied by the global eigenvector criteria using equation (6).

Global priority $=($ alternative eigenvector criteria $1 \times$ eigencriteria 1$)+$ (alternative eigenvector criteria $2 \mathrm{x}$ eigencriteria 2 )..n

To calculate the global priority for each Kos, first we collected the eigen values of the criteria in the alternative like in the eigen values of the criteria in the Mariyam Kos alternative. See Table 13.

Table 13. Eigen of Mariyam Kos Alternative

\begin{tabular}{|l|l|l|}
\hline Kode Kriteria & Nilai Eigen & Eigen Global \\
\hline H & 0.0495 & 0.25 \\
\hline F & 0.0727 & 0.22 \\
\hline KA & 0.0435 & 0.18 \\
\hline J & 0.0506 & 0.14 \\
\hline KN & 0.05 & 0.11 \\
\hline P & 0.0909 & 0.07 \\
\hline R & 0.0811 & 0.04 \\
\hline
\end{tabular}

The calculation process used equation 6.

Mariyam kos Priority Value

$=(0.0495 * 0.25)+(0.0727 * 0.22)+(0.0435 * 0.18)+(0.0506 * 0.14)+(0.05 * 0.11)+(0.0909 * 0.07)$ $+(0.0811 * 0.04)$

$=0.05721082$

So, the priority value on the Mariyam Kos alternative is 0.05721082 .

The results of calculations using global priorities can be seen in Table 14.

Table 14. Alternative calculation

\begin{tabular}{|l|l|l|l|l|l|l|l|l|l|l|l|}
\hline No & Alternatif & H & F & KA & J & KN & P & R & Eigen & Prioritas \\
\hline 1 & Mariyam Kos & 0.0495 & 0.0727 & 0.0435 & 0.0506 & 0.05 & 0.0909 & 0.0811 \\
\hline 2 & Hariyono Kos & 0.0497 & 0.0727 & 0.0435 & 0.0509 & 0.05 & 0.0455 & 0.0811 \\
\hline 3 & Deni Kos & 0.0499 & 0.0182 & 0.0435 & 0.0506 & 0.05 & 0.0455 & 0.0541 \\
\hline 4 & Budi Kos & 0.0502 & 0.0182 & 0.0435 & 0.0507 & 0.05 & 0.0455 & 0.0270 \\
\hline 5 & Sinta Kos & 0.0501 & 0.0182 & 0.0870 & 0.0508 & 0.05 & 0.0455 & 0.0270 \\
\hline 6 & Aldian Kos & 0.0504 & 0.0182 & 0.0435 & 0.0369 & 0.05 & 0.0455 & 0.0270 \\
\hline 7 & Doni Kos & 0.0497 & 0.0727 & 0.0435 & 0.0507 & 0.05 & 0.0455 & 0.0541 \\
\hline 8 & Munawar Kos & 0.0497 & 0.0727 & 0.0870 & 0.0506 & 0.05 & 0.0909 & 0.0811 \\
\hline 9 & Andreas Kos & 0.0505 & 0.0182 & 0.0435 & 0.0506 & 0.05 & 0.0455 & 0.0270 \\
\cline { 4 - 7 }
\end{tabular}




\begin{tabular}{|l|l|l|l|l|l|l|l|l|l|l|}
\hline No & Alternatif & H & F & KA & J & KN & P & R & Eigen & Prioritas \\
\hline 10 & Harry Kos & 0.0495 & 0.0727 & 0.0435 & 0.0506 & 0.05 & 0.0455 & 0.0811 \\
\hline 11 & Rika Kos & 0.0506 & 0.0182 & 0.0435 & 0.0506 & 0.05 & 0.0455 & 0.0270 \\
\hline 12 & Riski Kos & 0.0501 & 0.0727 & 0.0435 & 0.0507 & 0.05 & 0.0455 & 0.0541 \\
\hline 13 & Dedi Kos & 0.0506 & 0.0182 & 0.0435 & 0.0504 & 0.05 & 0.0455 & 0.0270 \\
\hline 14 & Dede Kos & 0.0504 & 0.0182 & 0.0435 & 0.0506 & 0.05 & 0.0455 & 0.0270 \\
\hline 15 & Anang Kos & 0.0505 & 0.0182 & 0.0435 & 0.0506 & 0.05 & 0.0455 & 0.0270 \\
\hline 16 & Mariya Kos & 0.0499 & 0.0727 & 0.0870 & 0.0508 & 0.05 & 0.0455 & 0.0541 \\
\hline 17 & Slamet Kos & 0.0493 & 0.0727 & 0.0435 & 0.0508 & 0.05 & 0.0455 & 0.0811 \\
\hline 18 & Diding Kos & 0.0495 & 0.1273 & 0.0435 & 0.0510 & 0.05 & 0.0455 & 0.0541 \\
\hline 19 & Yanto Kos & 0.0494 & 0.0727 & 0.0435 & 0.0506 & 0.05 & 0.0455 & 0.0811 \\
\hline 20 & Nurul Kos & 0.0506 & 0.0545 & 0.0435 & 0.0506 & 0.05 & 0.0455 & 0.0270 & 0.042578967 \\
\cline { 4 - 5 } & & 0.053108034 \\
\hline & & 0.042539415 \\
\hline
\end{tabular}

After obtaining the global priority, we then sorted the values from the highest to the lowest value, then normalized them in the form of a percent so that the difference in values between alternative costs is more visible. The ranking results can be seen in Table 15 .

Table 15. Alternative calculation

\begin{tabular}{|l|l|l|l|}
\hline No & Alternatif & Nilai & Normalisasi \\
\hline 1 & Munawar Kos & 0,063446024 & 6,3446024 \\
\hline 2 & Diding Kos & 0,062751032 & 6,2751032 \\
\hline 3 & Mariya Kos & 0,059279104 & 5,9279104 \\
\hline 4 & Mariyam Kos & 0,05721082 & 5,721082 \\
\hline 5 & Hariyono Kos & 0,054014794 & 5,4014794 \\
\hline 6 & Harry Kos & 0,053915366 & 5,3915366 \\
\hline 7 & Slamet Kos & 0,053910742 & 5,3910742 \\
\hline 8 & Yanto Kos & 0,053891635 & 5,3891635 \\
\hline 9 & Riski Kos & 0,053108034 & 5,3108034 \\
\hline 10 & Doni Kos & 0,05303392 & 5,303392 \\
\hline 11 & Nurul Kos & 0,049033512 & 4,9033512 \\
\hline 12 & Sinta Kos & 0,048690892 & 4,8690892 \\
\hline 13 & Deni Kos & 0,043366705 & 4,3366705 \\
\hline 14 & Rika Kos & 0,042578967 & 4,2578967 \\
\hline 15 & Anang Kos & 0,042563146 & 4,2563146 \\
\hline 16 & Andreas Kos & 0,042555236 & 4,2555236 \\
\hline 17 & Dede Kos & 0,042539415 & 4,2539415 \\
\hline 18 & Dedi Kos & 0,042521159 & 4,2521159 \\
\hline 19 & Budi Kos & 0,042504853 & 4,2504853 \\
\hline 20 & Aldian Kos & 0,039084642 & 3,9084642 \\
\hline & & & \\
\hline
\end{tabular}

\section{B. Data Modelling}

The table relations can be seen in Figure 3. 


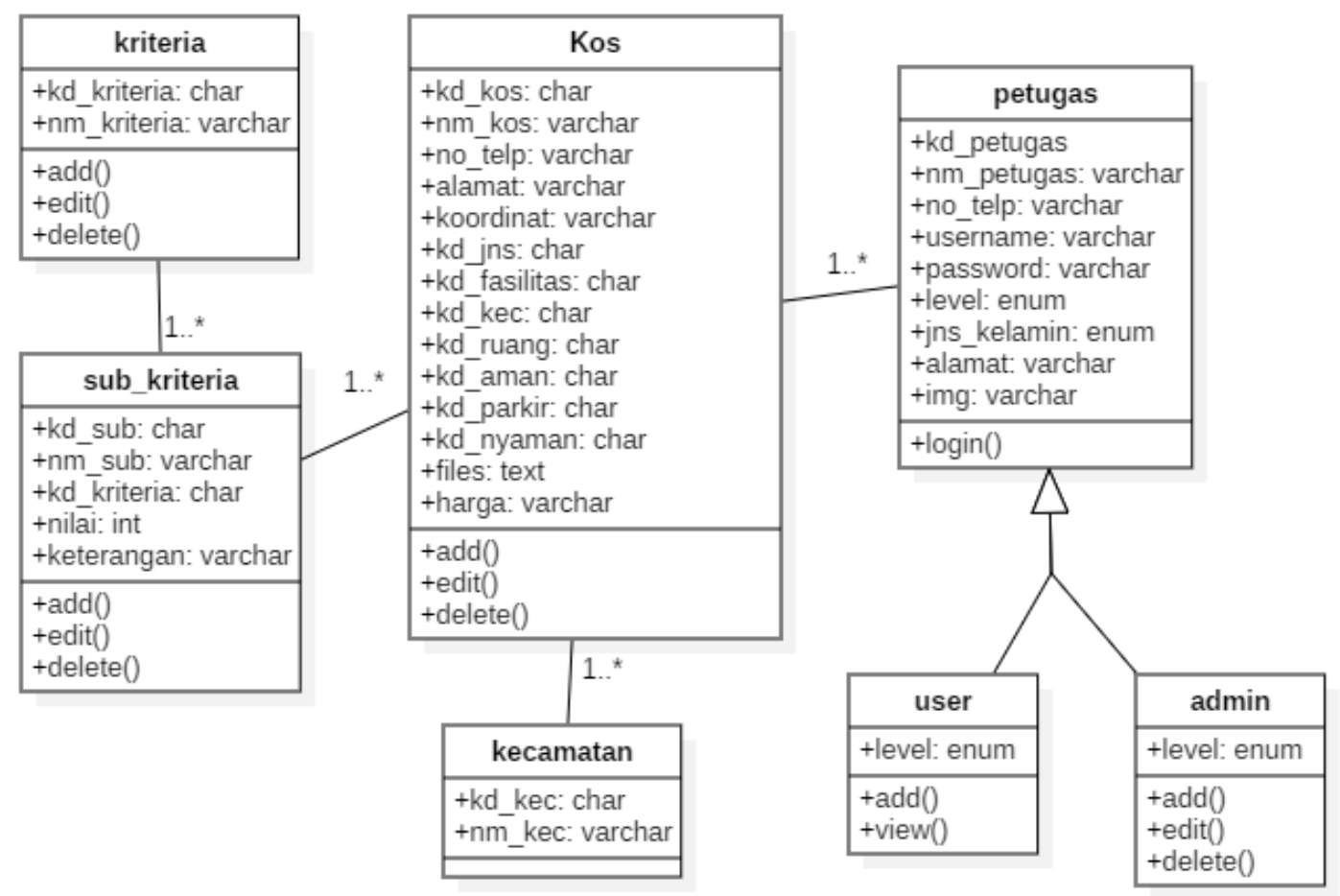

Figure 3. Data Modelling

\section{Conclusion}

Based on the results of tests and analysis, the following conclusions can be drawn 1) The boarding house searching process using the Analytic Network Process (ANP) method is dynamic, which means that the total priority can be increased or decreased as needed. 2) The results of calculations show that the highest value is $6.55 \%$, namely Munawar Kos and then Diding Kos with a value of $6.52 \%$. 3) When viewed as the chosen priority, the prices and facilities owned by Munawar Kos and Doni Kos are the same. However, Munawar Kos was in first place, while Doni Kos was in tenth place. From these results, the level of security of the boarding house is the determinant factor. Munawar Kos has a better level of security when compared to Doni Kos, even though Doni Kos is closer than Munawar Kos.

\section{Acknowledgement}

This research received funding from Universitas Mercu Buana through the Central Research Bureau.

\section{Reference}

[1] A. Rachmawati, "Membangun Informasi Layanan Umum Rumah Kos Melalui Aplikasi Berbasis Web," [Building Information on Public Service Boarding Houses Through Web-Based Applications] J. Ilm. FIFO, vol. 9, no. 2, p. 155, 2017, doi:10.22441/fifo.2017.v9i2009.

[2] B. Harijanto, N. A. Tamara, and Y. Ariyanto, "Pengembangan Aplikasi Pemilihan Kost Di Kota Malang Dengan Metode Ahp Dan Promethee," [Developing boarding house selection application in Malang City using the Ahp and Promethee Methods] J. Inform. Polynema, vol. 4, no. 3, p. 229, 2018, doi:10.33795/jip.v4i3.212.

[3] H. Supriyono and C. P. Sari, "Developing decision support systems using the weighted product method for house selection," AIP Conf. Proc., vol. 1977, 2018, doi:10.1063/1.5042905.

[4] U. Wardhani and M. A. Nur, "Sistem Pendukung Keputusan Pemilihan Tempat Kos Untuk Mahasiswa Di Luwuk Banggai Dengan Metode Saw (Simple Additive Weighting)," [Decision Support System for Choosing a Boarding Houses for Students in Luwuk Banggai Using the Saw Method (Simple Additive Weighting)] Jtriste, vol. 4, no. 1, pp. 9-14, 2017.

[5] M. Abdillah, Ilhamsyah, and R. Hidayati, "Penerapan Metode Analytic Network Process (ANP) Berbasis Android Sebagai Sistem Pendukung Keputusan Dalam Pemilihan Tempat Kos," [The Application of the Android-Based Analytic Network Process (ANP) Method as a Decision Support System in the Selection of Boarding Houses] J. Coding, Engineering System. computer. Untan, vol. 6, no. 03, pp. 12-22, 2018.

[6] N. Slamet, "Sistem penunjang keputusan pemilihan rumah kontrakan untuk keluarga di kota malang menggunakan metode fuzzy sugeno," [Decision support system for the selection of rent house for family in the city of malang using the fuzzy sugeno method] Dec. 2017. 
[7] E. Panggabean, "Sistem Pendukung Keputusan Penentuan Lokasi Perumahan Ideal Menggunakan Metode Fuzzy Simple Additive Weighting," [Decision Support System for Determining Ideal Housing Location Using Fuzzy Simple Additive Weighting Method] vol. IV, no. 1, pp. 12-17, 2015.

[8] I. Gunawan Indragunawan, D. Risdayati, and M. Si, "The function of implementation of social control to bording houses in simpang new tampan, pekanbaru," Riau University, 2017.

[9] F. Sudiran, "Potensi rumah kos-kostan di samarinda untuk menjadi mata pencaharian rakyat yang menghasilkan income sehingga menjadi profesi," [The potential of boarding houses in samarinda for people's livelihood that generating income to become a profession," LEGALITAS, vol. 2, no. 2, pp. 74-85, Apr. 2018, doi:10.31293/LG.V2I2.3393.

[10] S. J. D. R. Secretariat General of the House of Representatives of the Republic of Indonesia, "Peraturan Tata Tertib Dewan Perwakilan Rakyat Republik Indonesia (Keputusan DPR RI No.16/DPR RI/1999-2000)," [The Regulation of the Order of the House of Representatives of the Republic of Indonesia (DPR RI Decree No. 16/DPR RI/1999-2000)," 1999.

[11]D. Nuruliyah and A. Aji, “Edu Geography Analisis Preferensi Pemilihan ' Kos - Kosan' Mahasiswa Universitas Negeri," [Edu Geography Analysis of Preferences for Selecting Boarding Houses of State University Students] vol. 7, no. 2, pp. 95-103, 2019.

[12] B. Setyadin and M. Pd, "Analisis faktor-faktor yang menjadi pertimbangan mahasiswa dalam memilih tempat kos di kelurahan sumbersari kota malang," [Analysis of Consideration Factors by University Students in choosing a boarding house in Sumbersari Village, Malang City] no. 1, 2010.

[13]AH Azhar and RA Destari, "Optimasi Decision Support System (DSS) Pemilihan Paket Layanan Internet Prabayar Dengan Metode ANP," [The Optimization of Decision Support System (DSS) Selection of Prepaid Internet Service Packages Using the ANP Method] J-SAKTI (Jurnal Sains Komput. dan Inform., vol. 3, no. 2, p. 183 , 2019, doi:10.30645/j-sakti.v3i2.139.

[14]A. Rusydiana, Aam S; Devi, “Analytic Network Process : Pengantar Teori dan Aplikasi," [Analytic Network Process: An Introduction to Theory and Applications] 2013.

[15]A. H. Azhar, R. A. Destari, L. Wahyuni, and F. Harahap, "Improvement accuracy of oil meal packaging with ANP method,” 2017 5th Int. conf. CyberIT Serv. Manag. CITSM 2017, 2017, doi:10.109/CITSM.2017.8089309.

[16]W. A. Syafei, K. Kusnadi, and B. Surarso, "Penentuan Priorita Perbaikan Jalan Berbasis Metode Analytic Network Process Sebagai Komponen Menuju Kota Cerdas," [Priority Determination of Road Improvement Based on Analytic Network Process Method as Component Towards Smart City] J. Sist. inf. Business, vol. 6, no. 2, p. 105, 2016, doi:10.21456/vol6iss2pp105-113.

[17]M. S. Bathin and D. Ramayanti, “SOBATHUNI : Aplikasi Rumah Sewa Berbasis Web,” [SOBATHUNI: WebBased Rental House Applications] J. Edukasi dan Peneliti. Inform., vol. 5, no. 2, p. 183, 2019, doi:10.26418/jp.v5i2.330452. 